\title{
Welfare - Focusing on the Neediest with a Simple Scoring Model
}

\begin{abstract}
This chapter describes the introduction of a new welfare formula in Georgia that replaced a myriad of pre-existing social subsidies and tax breaks, many of which had been introduced to win the favor of voters prior to elections. These subsidies were flat and tied to all manner of products and services, from electricity to public transport, and they benefitted very different groups of people, from single mothers to war veterans. In a bold move, the new government froze most of these subsidies. To make sure that what little funds were available in the post-reform budget went to the neediest people, a scoring model for poverty based on property and living expenses was introduced. Based on this model the "[p] overty rates decreased from 21 percent in 2010 to less than 15 percent in 2012, and extreme poverty decreased from 7 percent in 2010 to 4 percent in 2012" (according to the Word Bank).
\end{abstract}

Keywords Poverty · Pension · Formula · Disproportionately · Benefits · Household

Corruption is already a thing of the past. The fiscal footprint of the state is cut down to size, providing stability and promoting long-term sustainability of the national economy. Taxes and customs are minimized, and the administration is streamlined to provide citizens and entrepreneurs with easy access to government agencies and institutions. Case closed? Not quite. One challenge remains: finding a way to ensure that government

(C) The Author(s) 2017

N. Gilauri, Practical Economics, DOI 10.1007/978-3-319-45769-7_8 
funds are used wisely to support the future growth and prosperity of the country, and the well-being of its citizens. It's not enough to take one smart decision, or ten, or a hundred. The real challenge is to embed sustainable financing of public services in public policy. In other words, the challenge is to trigger a virtuous cycle and build a legacy of smart spending.

\subsection{Welfare in Georgia Before 2004}

At the turn of the millennium, Georgia was facing bankruptcy. This was largely due to the fact that a myriad of social subsidies and tax breaks had been introduced over time, usually to win the favor of voters prior to an election. These subsidies included all kinds of products and services, from gas and electricity to public transport and housing, and they were designed to benefit very different groups of people, from single mothers and large families to war veterans. In a bold move, the government transformed most of these flat subsidies into means-tested supports. ${ }^{1}$ To make sure that what little funds were available in the post-reform budget went to the neediest people, a scoring model for poverty based on property and living expenses was introduced. In most cases, income was disregarded because it would have been too difficult to track, given that most low-paying jobs were part of the gray economy at the time. Based on this model, the new department of welfare singled out the 20 percent of the population that was most in need of assistance.

\subsection{Social Subsidies as Electoral Bribes}

Every country, be it developing or developed, piles up new types of welfare support with every election cycle. Before an election, every party comes up with new ideas for wealth redistribution to win the favor of the electorate. These ideas take different shapes (direct subsidies, tax credits, tax incentives), and they target different groups of voters, depending on whose votes are most contested in a given election. After the election, the winning party is under pressure to keep some, if not all, of its promises.

Fortunately, Otto von Bismarck was right when he said that "people never lie as much as after a hunt, during a war, and before an election." 2 If all pre-election promises to shower the electorate with wealth and favors were actually kept, many countries, if not the whole world, would long have gone bankrupt by now. Yet far too many welfare promises 
become a costly reality. Although such politically motivated subsidies are often a very inefficient means to fight poverty and promote prosperity, the next generation of politicians is usually hesitant to reduce or abolish any of them, lest they lose the favor of those who benefit from the subsidies. As a result, the subsidies remain in place until the next crisis. And it takes a really serious crisis to clean up the mess and put together a smart, efficient, well-balanced welfare system. And even if you get it done, chances are it won't last forever. With the next electoral cycle, the pile-up will start all over again. In this respect, a truly serious crisis is an opportunity. In the case of Georgia in the early 2000s, it was the imminent bankruptcy of the state that put the government in a position to start from scratch. Elsewhere, the opportunity might arise from a serious geopolitical challenge or a fundamental regime change, such as the introduction of a new form of government.

At the time, Georgia's welfare system consisted of dozens of different subsidies, tax breaks, and cash payouts to a wide and diverse range of beneficiaries. In fact, the Georgian welfare system was like a log of the country's history in many respects. It comprised cash support for veterans and family members of those who died in the Second World War, veterans and family members of those who died in the Soviet war in Afghanistan, veterans and family members of those who died in the war for the independence and sovereignty of Georgia (in the occupied territories of Abkhazia and the Tskhinvali region), for political victims of Soviet rule and members of their families, for people who suffered injuries at the hands of the Soviet army during the Tbilisi massacre in April 1989 and members of the families of those who died there, for those who went to Chernobyl after the nuclear reactor catastrophe, and displaced persons from Abkhazia or the Tskhinvali region. Additionally, there were social welfare benefits for various groups: single mothers, families with five or more children, people with physical disabilities (first, second, and third grade), and pensioners - men above the age of 65 and women above the age of 60 . The full list was much longer, and there were additional healthcare subsidies for some of these groups.

\subsection{CORRUPtion ANd INEFFICIENCY}

On top of the cash payouts and healthcare subsidies, the Georgian welfare system comprised many non-cash subsidies for specific groups such as pensioners, students, and internally displaced persons. Examples include 
transport, electricity, gas, and schoolbooks. Finally, there were some tax and customs incentives. Cigarette imports, for instance, were exempt from customs payment for people with physical disabilities during a certain period. While the exemption may have been well intentioned at the time, it was quickly exploited by criminals. Suddenly, every importer was a disabled person. Of course, these individuals only acted as straw men for companies that did their business behind the scenes. Corruption was common in other areas as well. People bribed doctors to issue false disability certificates, or used the names of deceased family members to receive pensions, leading the authorities to believe that these pensioners were still alive. Others got even more creative and invented identities solely to swindle the government. Around 2007, the number of Second World War veterans started to increase, when it should, naturally have been decreasing as aging veterans passed away. Apparently, somebody had found "new" veterans who had eluded registration before. Of course, these claims turned out to be fraudulent.

The benefits often didn't reach those they were intended for, or at least not in full. And while the list of beneficiaries may sound plausible at first, the total number of those entitled to some sort of subsidy was so high that the amount received by a given family or individual was often shamefully small. For example, the average pension for the elderly only came to about USD 8-9 per month before 2004, and even that small sum was not paid by the government in full, or in time. Similarly, the monthly cash benefit for a disabled or internally displaced person was only USD 5-6, and that wasn't fully paid out either. On the flip side, some recipients didn't need the subsidies at all. For example, some displaced persons were wealthy individuals for whom the subsidies were a welcome but entirely unnecessary source of additional income.

In effect, the entire system was highly inefficient. It didn't reliably provide support to the neediest, and it awarded benefits to many people who didn't need them. The inadequacy of the system was apparent to all, but almost everybody had something to lose from fixing it, which is why Georgia had to get so close to bankruptcy for things to change.

\subsection{INBUilt INERTIA}

Even after the Rose Revolution, it was initially impossible to get rid of any subsidies, or even ward off the introduction of new benefits. How do you say no to single mothers and struggling families? Every time the new 
government went to parliament with a new budget, the opposition would argue that it's well and good to support families with more than five children, but why not support families with three or four children as well? Why not give more money to needy children directly? In the absence of a sound political culture - a big issue in many developing countries - the opposition does not have to come up with ways of financing such demands. Voters like what they hear, and it becomes even more difficult for any government to say no. In fact, this vicious cycle of demands and promises was one of the key drivers that brought Georgia to the brink of bankruptcy in early 2000's. This kind of vicious cycle is not at all uncommon. Similar systems are found in many other countries, developing as well as developed, and they are almost always plagued by corruption and inefficiency to some extent.

\subsection{Starting From Scratch with a Scoring Model}

In Georgia, the financial situation got so serious that the government had no choice but to start from scratch and come up with an entirely new approach to social welfare. The only fair solution was, and still is, to identify the poorest segments of society and assist them, regardless of whether they are single mothers, families with five children, or displaced persons.

The governing idea was very simple. Georgia is not a rich country. It cannot afford to waste its resources on those who are relatively wealthy when many of the poor are going unassisted. Increasing taxes to finance social expenditure was out of the question because of the crisis the national economy was in. Any tax increase would have been disastrous for the newly developing private sector. The government had to minimize the inefficiencies and target the neediest with what little means it had. To this end, the government issued an announcement: "If you deem yourself poor, please register at the nearest government office to apply for assistance." Approximately 28 percent of all Georgians applied. Also, it quickly became obvious that some people had applied just to try their luck. For example, the list of applicants included some businessmen who were hoping for special tax breaks. A special department was created to develop a scoring model for all households.

It took a while to come up with a workable formula. The initial scoring model was mainly based on ownership, rather than income or expenses. This was because income was largely unregistered, especially for the 
poorest parts of society. Their income came from small-scale trade, from selling homegrown produce, or subsistence farming. The original list of line items that were incorporated into the formula included land, houses, apartments, and automobiles - all obviously relevant to determine, or at least approximate, someone's wealth from a property perspective. But the original list also included many other, less obvious items such as carpets, curtains, mobile phones, TV sets, and other electronic appliances. Many of these items were gifts from wealthier relatives, or had been left to families as part of an inheritance, which is why this approach caused significant frustration among the population. It took many iterations to develop a fairer formula. In the end, we settled on a formula essentially based on two pillars: proven property (land, house, apartment, and vehicle) and verifiable expenses (rent, mobile phone bill, electricity bill, and gas and water utility bill). Income is also part of the formula, but its weight is minimal as most of the prospective beneficiaries operated in the gray economy or had in-kind income, which made it impossible, or disproportionately difficult, to quantify their income in a reliable fashion.

The calculation of the welfare index for each applicant was based on the results of an interview conducted by a social worker, using a questionnaire that covered all the parameters used in the formula. The household welfare index was calculated according to the formula $I=C / N$, where $C$ is a household consumption index and $N$ is a household needs index. The lower the resulting welfare index, the lower the household welfare level. The household consumption index itself was calculated according to the following formula:

$$
C=\exp \left(L_{0}+\sum_{i=1}^{10} C_{i}\right)
$$

In this formula, $L_{0}$ is a base coefficient. Summands $C_{1}$ through $C_{10}$ are index values for parameters such as land use, livestock ownership, non-agricultural property, income, expenses, demography, education, skills, living conditions, and territory. ${ }^{3}$

A new department of welfare was created to implement the new formula. Many of its social workers were hired straight out of university. Every single application for social subsidies was checked, and often re-checked, to prevent any corrupt deals between government agents and applicants. 
It turned out that approximately a quarter of the applicants did not meet the government's criteria for poverty, a wealth score below 120,000 points. While some entrepreneurs and owners of businesses had applied, hoping for special tax cuts or tax credits (as mentioned above) others were simply trying their luck. One family went so far as to take all furniture from one house to another. They submitted a forged rental agreement and showed the social worker around their empty house, claiming that they didn't own anything and didn't have any income. Ultimately, one-fifth of the population was identified as poor and, hence, entitled to some kind of financial assistance. Most of these households were already receiving some benefits from existing programs.

In the first year of the reform, it was decided that every household with a score below 57,000 would receive a cash benefit of approximately USD 20 per person per month. Why USD 20? Why every household with less than 57,000 points? Because this was exactly what was affordable within the limits of the budget at that time. All non-cash subsidies were abolished, and the funds that were freed up were used to finance the new, score-based cash program. The department of welfare gave money to the poorest and let them use it as they saw fit - on transportation, on utility payments, or on food, assuming that every individual is the best judge of what they need the most.

In the second phase, the same group of beneficiaries (members of households with a score below 57,000 points) received medical insurance vouchers on top of the cash assistance (see later in the text). In the third year, some 15 percent of households scoring between 57,000 and 70,000 points also received insurance vouchers. No cash benefits were awarded to this new group, as this would have exceeded the long-term financial means of the government. The ultimate test of any new measure was the long-term viability of the welfare system, irrespective of a given year's financial resources. The idea was, and still is, to verify the entitlement of beneficiaries on an annual basis by determining their scores, to give assistance only in cash, or in insurance vouchers, to the poorest as warranted by the long-term financial means of the government. Of course, it remains very difficult from a political perspective to remove any household from the list of beneficiaries, especially in an election year. This fact has weakened the reform, but the new system is still far superior to the preceding chaos. As a next step, the government may want to think about replacing the threshold-based approach with a sliding scale allocation of assistance (i.e., cash paid out in direct proportion to a 
household's score). This will put an end to relative injustices, such as a household with the score of 56,999 receiving the full assistance and another one, with a score of 57,001 , not receiving anything.

The new formula was first introduced in Georgia in 2006. It had many flaws, and many mistakes were made; but as a result of continuous improvements to the formula and to its administration, the results were outstanding. Of course, Georgia's overall economic growth also helped. According to the World Bank, the Georgian welfare program was one of the most successful in the world in terms of targeting the neediest: "Poverty rates decreased from 21 percent in 2010 to less than 15 percent in 2012, and extreme poverty decreased from 7 percent in 2010 to 4 percent in 2012." 4

Despite the very successful reform, some subsidies survived. The plan was to phase them out over time. However, during the next political cycle, some former subsidies were resurrected, e.g., the subsidy of public transport for pensioners. I still believe that the welfare reform conducted in Georgia between 2006 and 2010 was very successful, and that many countries would benefit from introducing similar systems. The central idea is as simple as it is powerful: put an end to a myriad of subsidies and non-cash flat benefits to different, partly random groups of beneficiaries. Instead, identify the neediest, categorize them based on their financial means, and provide them with cash assistance to the extent that the government can afford. Let the neediest decide how to spend these funds. Stay away from non-cash flat subsidies or tax breaks that will often make the rich richer, rather than help the poor. For example, if the government subsidizes gas (petrol), those who consume the most - drivers of sports cars, or owners of a fleet of trucks - will benefit the most.

When the government of Georgia went to parliament with the new system, it was easy to counter the opposition's questions and demands with fact-based replies: "Yes, we provide welfare assistance to single mothers, as well as to families with five or more children. In fact, we even help families with two or three children. We give assistance to people with disabilities, and they get more than they did in the past. But we give money only to those families who need the assistance the most. Georgia cannot afford to give money to rich people with disabilities, or to rich families with seven children." Politically, getting parliamentary approval for a new budget, or any type of reform, had never been easier. 


\section{Notes}

1. No new beneficiaries were accepted into these programs. Existing beneficiaries were given a choice to keep receiving the old subsidies or to upgrade to the new formula, which resulted in higher total payments. Of course, everybody chose the new welfare program. Effectively, most of the old subsidies seized to exist.

2. Im neuen Reich: Wochenschrift für das Leben des deutschen Volkes in Staat, Wissenschaft und Kunst, Band 1; Band 9; Verlag von S. Hirzel, 1879, p. 199.

3. Household welfare level evaluation methodology; internal document available through the author.

4. http://www.worldbank.org/en/results/2014/04/15/supporting-inclu sive-growth-and-development-in-georgia (retrieved in April 2014).

Open Access This chapter is distributed under the terms of the Creative Commons Attribution 4.0 International License (http://creativecommons.org/licenses/by/4.0/), which permits use, duplication, adaptation, distribution and reproduction in any medium or format, as long as you give appropriate credit to the original author(s) and the source, provide a link to the Creative Commons license and indicate if changes were made.

The images or other third party material in this chapter are included in the work's Creative Commons license, unless indicated otherwise in the credit line; if such material is not included in the work's Creative Commons license and the respective action is not permitted by statutory regulation, users will need to obtain permission from the license holder to duplicate, adapt or reproduce the material.

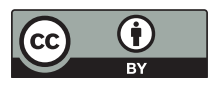

